\title{
Testosterone and the Brain: From Cognition to Autism
}

\author{
Daniela OSTATNÍKOVÁ ${ }^{1}$, Silvia LAKATOŠOVÁ ${ }^{\mathbf{1}}$, Jaroslava BABKOVÁ ${ }^{\mathbf{1}}$, Július \\ HODOSY ${ }^{1,2,3}$, Peter CELEC ${ }^{1,2}$
}

${ }^{1}$ Institute of Physiology, Academic Research Centre for Autism, Faculty of Medicine, Comenius University, Bratislava, Slovak Republic, ${ }^{2}$ Institute of Molecular Biomedicine, Faculty of Medicine, Comenius University, Bratislava, Slovak Republic, ${ }^{3}$ University Hospital, Bratislava, Slovak Republic

Received March 30, 2020

Accepted October 6, 2020

\section{Summary}

Sex and gender matter in all aspects of life. Humans exhibit sexual dimorphism in anatomy, physiology, but also pathology. Many of the differences are due to sex chromosomes and, thus, genetics, other due to endocrine factors such as sex hormones, some are of social origin. Over the past decades, huge number of scientific studies have revealed striking sex differences of the human brain with remarkable behavioral and cognitive consequences. Prenatal and postnatal testosterone influence brain structures and functions, respectively. Cognitive sex differences include especially certain spatial and language tasks, but they also affect many other aspects of the neurotypical brain. Sex differences of the brain are also relevant for the pathogenesis of neuropsychiatric disorders such as autism spectrum disorders, which are much more prevalent in the male population. Structural dimorphism in the human brain was welldescribed, but recent controversies now question its importance. On the other hand, solid evidence exists regarding gender differences in several brain functions. This review tries to summarize the current understanding of the complexity of the effects of testosterone on brain with special focus on their role in the known sex differences in healthy individuals and people in the autism spectrum.

\section{Key words}

Androgen • Intelligence - Psychoneuroendocrinology • Sex steroids • Mental rotation

\section{Corresponding author}

D. Ostatníková, Institute of Physiology, Faculty of Medicine,
Comenius University, Sasinkova 2, 81108 Bratislava, Slovak Republic. E-mail: daniela.ostatnikova@fmed.uniba.sk

\section{Introduction}

Humans as sexually reproducing living beings exhibit sexual dimorphism with well-known sex or gender differences in anatomy, physiology and pathophysiology. While sex refers to biological characteristics assigned at birth based on reproductive organs and main sex hormones they produce, gender represents person's social and cultural role based on one's identity. Over the past decades research has revealed a number of sex differences in the human brain with remarkable functional behavioral and cognitive consequences (Collaer and Hines 1995, Hedges and Nowell 1995, Gur et al. 1999). Androgens are key regulators of male sexual differentiation and development of a normal male phenotype. The main human androgen testosterone plays a dominant role in sexual dimorphism (Durdiakova et al. 2011). Genetic and environmental effects modulating gene expression of enzymes for steroid metabolism in the steroidogenic cascade in concordance with the modulation of expression of respective receptors imply complex and sophisticated mechanisms of androgen effects. In addition, the nongenomic effects of testosterone on behavior bypassing the nuclear receptors have attracted the interest of researchers and might complicate the general understanding (Filova et al. 2015a, Filova et al. 2015b). But they might explain 
some of the puzzling observations of non-linear associations between testosterone and brain functions from the past (Celec et al. 2015). Testosterone and other sex steroids are not the only cause for sex differences. Testosterone itself is under genetic control, although this is complex and indirect (Harden et al. 2014). The role of sex-different androgen receptor gene dose due to its location on the $\mathrm{X}$ chromosome might be involved. The overall testosterone/androgen signaling is determined by numerous factors from genes, over their usage to various environmental factors including physical exercise and phytoestrogen intake (Celec et al. 2007a, Hodosy et al. 2012a). It should be noted that sex differences and their mechanisms might vary during the development and be completely different in aging (Domonkos et al. 2017a).

\section{Effects of testosterone on brain during the life span}

The effect of testosterone on sexual differentiation of the reproductive system depends on the concentrations of androgens during the critical periods of prenatal life (Wilson and Davies 2007). The actions of sex steroids on brain and behavior traditionally have been divided into organizational and activational effects. Organizational effects are permanent and occur early in development; activational effects are transient and occur throughout life (Arnold and Breedlove 1985). In human as early as in the $7^{\text {th }}$ week of gestation, testes begin to secrete testosterone and determine male typical genitalia (Ivell et al. 2017). Testosterone is involved also in the sexual differentiation of the behavior (Auyeung et al. $2009 \mathrm{~b}$ ). The surge of this hormone in male fetuses between $16^{\text {th }}$ and $24^{\text {th }}$ week of gestation mediates the socalled organizational effect (Auyeung et al. 2009c). High concentrations of testosterone during this period are crucial for the differentiation of androgen dependent tissues including specific brain areas (Connolly and Resko 1994, Hiort 2013). In humans, the prepubertal period lasts approximately from year 1 to year 8 , as the endogenous gonadal steroids remain in relatively stable low concentrations. A wide spectrum of endocrine changes is associated with the maturation of the reproduction function during the adolescent period testosterone production peaks again and remains relatively stable during the fertile period of life respecting biological fluctuations and rhythms (Oerter et al. 1990, Celec et al. 2002, Celec et al. 2009a). The critical period for cyclicity induction in girls is likely the pubertal transition (Barbieri, 2014). But although it is assumed that this is valid only for women, the true cyclicity of testosterone was found to be even higher in men (Celec et al. 2003). So, the general knowledge on the acyclicity of men might be challenged in the near future. The critical period for cyclicity induction in girls is likely the pubertal transition (Barbieri 2014). But although it is assumed that this is valid only for women, the true cyclicity of testosterone was found to be even higher in men (Celec et al. 2003). So, the general knowledge on the acyclicity of men might be challenged $i$ the near future. Both, prenatal and postnatal exposure lead to structural and functional consequences that are both, time and dose dependent (Hines 2006). Particular attention is given to the role of prenatal hormone exposure, which appears to be vital for early organization of the brain (Collaer and Hines 1995, Chura et al. 2010). In later life, testosterone is found to influence the behavior, but the effect is a kind of activation or fine-tuning of the already established early organization of the brain (Romeo et al. 2002, Schulz et al. 2009). Organizational effects produce permanent changes in the wiring and sensitivity of the brain areas and are largely irreversible. Activational effects occur later in life and are associated with changes of circulating testosterone levels, which activate neural systems organized early in life (Celec et al. 2015). However, as shown in our experiment, prenatal testosterone affects postnatal hormonal status and, thus, a clear experimental division of organizational and activational effects is nearly impossible (Domonkos et al. 2017b).

Organizational effects of testosterone may prime the brain structures by changing its responsivity to the hormonal fluctuations later in life (Cohen-Bendahan et al. 2005). Due to ethical constraints it is extremely difficult to analyze prenatal testosterone concentrations. It has been proposed that the ratio of the second to fourth digit lengths (2D:4D) may be a proxy of prenatal androgen exposure. Low 2D:4D ratio is associated with high prenatal androgen exposure (Manning et al. 1998, Manning et al. 2000, Manning and Robinson 2003, Manning and Fink 2008, Beaton et al. 2011). Activational effect reflects the influence of actual hormonal concentrations on preprogrammed brain structures with behavioral and cognitive consequences (Goel and Bale 2008). We have previously shown that low 2D:4D associated with higher prenatal testosterone was also associated with lower empathy in intellectually gifted boys (Durdiakova et al. 2015). On the other hand, 
experimentally we have not proved that exogenous testosterone lowers the 2D:4D in mice (Suchonova et al. 2019).

The so-called organizational-activational hypothesis is old, but fascinating concept on how sex differences in mating behavior are induced by prenatal testosterone (Phoenix et al. 1959). Later the hypothesis has been widen to include all sex differences in brain functions and even to all other organs and tissues (Arnold 2009). The mechanisms underlying the organizational effects have been studied extensively, but the picture is still not complete. It is clear that it includes the conversion of testosterone to estradiol by aromatase, at least for the effects on the brain (McCarthy et al. 2009). The hypothesis, however, is not generally accepted. Testosterone has been shown to affect plasticity of the brain even in the adulthood (Losecaat Vermeer et al. 2016). This means that the organizational effects are not limited to the prenatal period, but in contrast to the activational effects might rather be mediated by other receptors and signaling pathways.

Metabolism of testosterone contributes to the complexity of its actions. Testosterone does not only act per se, but also via the products of its metabolism. Reduction to dihydrotestosterone by 5-alpha reductase increases the androgen activity, conversion to estradiol by aromatase converts the androgen to estrogen activity (Filova et al. 2013). The biological effects of testosterone depend on the sensitivity of androgen receptor, that is affected by the genetic variation of the androgen receptor gene (Hillmer et al. 2005). Genetic variation in steroid receptors and enzymes related to steroid metabolism is crucial for understanding of endocrine phenotypic variability. Several studies examined the association between (CAG)n polymorphism and cognitive abilities (Yaffe et al. 2003, Lee et al. 2010). In the range of normal variation low number of (CAG)n repeats cause higher transactivational activity (more intense activation of transcription of the regulated genes) of receptor and, thus, higher sensitivity to androgens (Irvine et al. 2000, Greenland et al. 2004). Genetic and environmental factors determine the effects and the role of testosterone in physiology and pathogenesis of neurodevelopmental disorders (Fig. 1).

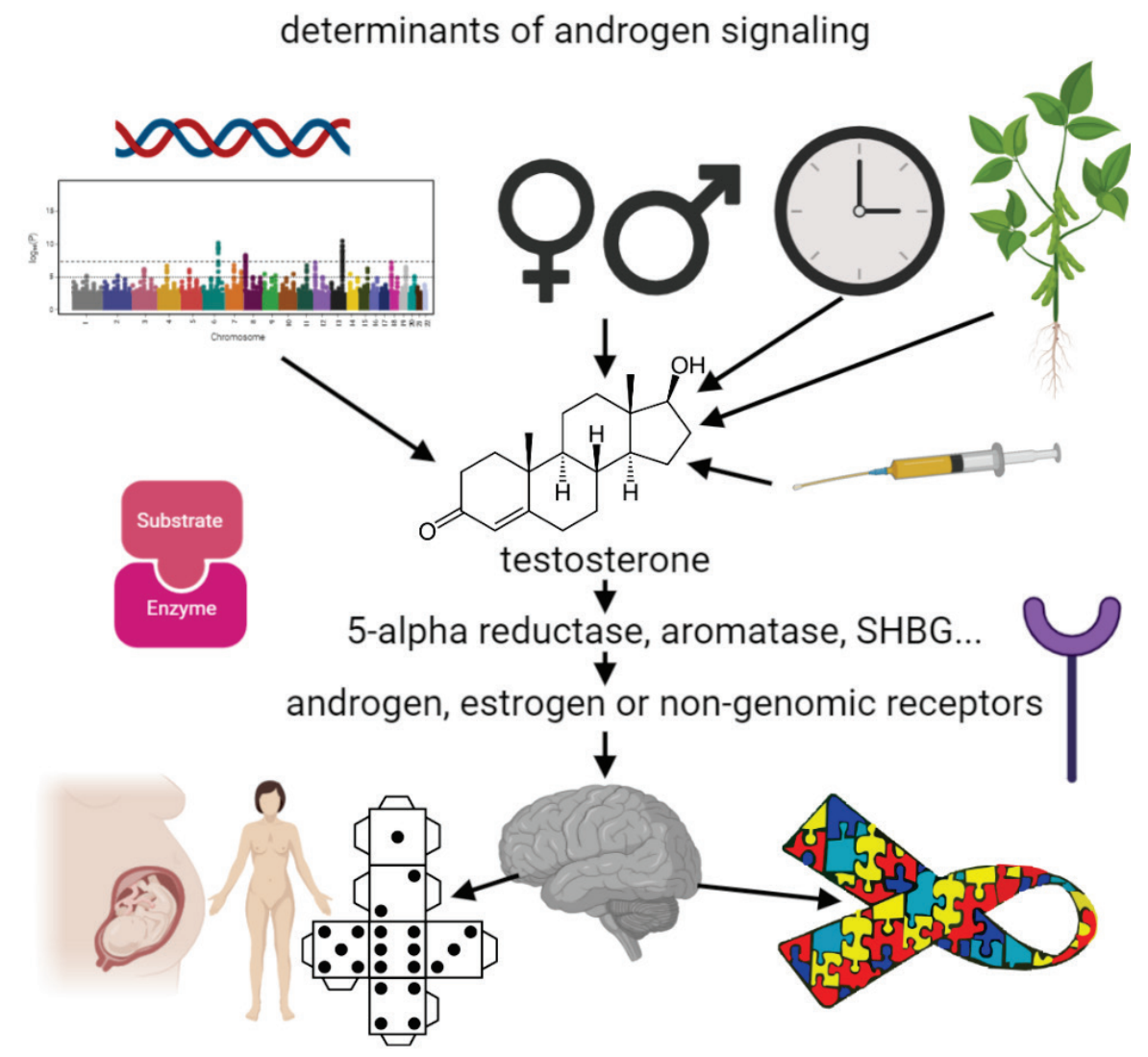

Fig. 1. Causes and consequences of testosterone/androgen signaling variability on the brain. Genetic variants, sex differences, endocrine biorhythms, phytoestrogens in the nutrition, treatments affect the concentration of testosterone as well as its metabolism and recognition by the corresponding receptors. Activational and organizational effects on the brain and its functions such as spatial abilities are physiological. Testosterone, however, also increases the risk of developmental disorders such as autism. 
Testosterone in relation to anatomical and functional brain differences

Structural sex differences in the human brain are of interest for the understanding of both, differences in physiological psychological traits and psychiatric disorders. It is suggested that the presence, magnitude, and direction of observed sex differences strongly depend on (1) the brain structure examined (cerebral cortex, corpus callosum, etc.), (2) on the specific brain feature assessed (cortical thickness, cortical convolution, etc.), (3) on the degree of regional specificity (global gray matter volume, voxel-wise gray matter volume, etc.), and (4) whether measurements are adjusted for individual brain size or not (Luders and Toga 2010). There are few studies providing the insight into the adult brain structure and function. One of the biggest studies reported on sex differences studied in 2750 female and 2466 male participants from a UK biobank (Ritchie et al. 2018). Males showed higher raw volumes, raw surface areas and white matter fractional anisotropy; females had on the other side higher raw cortical thickness and higher white matter tract complexity. This implies that the average male brain is better adapted for connecting sensory perception with coordinated motor activity, while average female brain is structured for enhanced communication between analytic and intuitive processing (Ingalhalikar et al. 2014). Most of the differences were observed on adults. But the question remains when the sexually dimorphic brains develop. Studies in newborns and infants have shown that already at this stage males and females vary in brain volume and cortical thickness (Knickmeyer et al. 2005, Choe et al. 2013) implicating a likely emergence of sexual dimorphism in the brain before birth. Gao and colleagues assessed brain functional connectivity at birth, at the age of 1 and 2 years and observed greater age-dependent increase in frontoparietal connectivity in males than females (Gao et al. 2015b). However, no other sex differences in network connectivity were observed. In another study no differences were observed in developmental trajectories for cortical growth or myelination of brain regions between male and female brains at the ages of 1-6 years (Deoni et al. 2015).

Sexual differentiation was supposed to occur in the first weeks of life (Hines 2010). One of the most consistent dimorphic findings is that male infants, children and adults have greater whole-brain volume than females (Gilmore et al. 2007, Koolschijn and Crone
2013). A number of structural elements in the human brain differ between males and females. "Structural" refers to actual parts of the brain and the way they are built, including their size and/or mass. Specifically, males have been documented to have larger prefrontal cortex, amygdala, and hippocampi than females (Ruigrok et al. 2014). However, it is important not only to describe regional differences in structure, but also the connectivity between regions and how these connections differ early in development between males and females in utero. Females often have a higher density of neural connections into the hippocampus. Regional differences in brain function developed in utero may predispose individuals to specific abilities, and also to health outcomes later in life (DiPietro and Voegtline 2017).

Male and female brains process the same neurochemicals but in different concentrations and through sex-specific connections. One dominant neurochemical is testosterone mostly known as sex and aggression hormone that has a profound influence on brain structures and functions. Individual variations of testosterone in relation to other hormones within the brain lead to a fluctuating neuroendocrine milieu that has an impact on typical male behavior using different strategies in problem solving and decision making (Gouchie and Kimura 1991). Testosterone influences cognitive styles based on the principles of the empathizing-systemizing theory of typical sex differrences, proposing that females on average have a stronger drive to empathize - to identify thoughts and feelings of other persons and to respond to these with an appropriate emotion, while males on average have a stronger drive to systemize - to analyze or construct rule-based systems (Baron-Cohen 2002). Possible biological mechanisms include the effect of fetal sex steroids or the role of sex chromosomes. Sex steroid hormones have the capacity for epigenetic modulation of neuronal functions and fetal brain development during early critical periods (Auyeung et al. 2009b, Lombardo et al. 2012).

According to the callosal theory, prenatal testosterone mediates early axon pruning in callosal tissue, and thus the higher the prenatal testosterone, the more lateralization occurs in the brain (Witelson and Nowakowski 1991, Ypsilanti et al. 2008). Additionally, before boys or girls are born, their brains develope with different divisions of labor between hemispheres. The male brain is set up for better connecting sensory information with coordinated activity, while female brain 
is predisposed for communication between analytic and intuitive processing (Ingalhalikar et al. 2014). As a result, girls and women tend to receive more sensorial and emotive information than males do. Both, girls and women tend to sense a lot more of what is going on around and they retain sensorial information longer than men (Chura et al. 2010).

\section{Testosterone effect on intelligence}

Individual differences in general cognitive ability can be measured by the intelligence quotient (IQ), which assesses abilities including planning, reasoning, comprehension, abstraction and learning (Deary 2013). IQ is also strongly predictive of various important life outcomes including educational achievement, occupational attainment, social mobility and job performance (Deary et al. 2007). Compared with females, males produce much more testosterone, which triggers a cascade of reactions that culminate in the masculinization of genital tissue and of the developing nervous system. There are several unique neurobiological features present in the majority of academically gifted population supporting the connection between extraordinary intelligence and brain pattern development. Although it has been not entirely understood how the development of the central nervous system can be affected by testosterone, suggestive data have accumulated to prove that testosterone act on the brain structure and architecture (de Lacoste et al. 1991, Hilleke et al. 2006, Beking et al. 2018). While no difference was found in mean IQ between boys and girls, there was a difference in the proportion of boys and girls in the intellectually gifted group and also in the mentally disabled group: both groups contained more males than females (Ostatnikova et al. 2000). This was in accordance with findings of other researchers who observed greater variability in intellectual performance among boys (Hyde et al. 1990, Johnson et al. 2008). Researchers have found more male than female pre-adolescents and adolescents in groups of above-average ability (Benbow 1988, Hyde et al. 1990). Sex differences in the occurrence of neurodevelopmental disorders have been reported with males being more often affected, including severe mental retardation, language disorders, learning difficulties and others, irrespective of race and severity of disability (Flannery et al. 2000, Liederman et al. 2005). Intellectual giftedness defined as an IQ score of 130 or higher is associated with prenatal testosterone (Mrazik and
Dombrowski 2010). The hypothesis is that similarly to physical and cognitive deficiencies that may develop in utero, in utero exposure to testosterone might result in intellectual giftedness. In the attempt to find the biological correlate for intellectual ability, our research group correlated salivary testosterone levels with general intelligence in preadolescent academically gifted participants and general population controls (Ostatnikova et al. 2000). Salivary testosterone levels in the control group of children attending regular primary school were compared with those in the group of intellectually gifted children scoring 130 or more in the independent standardized intelligence tests. The results proved significant differences in all ages - from the age of 5 till the age of 8 . Lower testosterone concentrations were found in academically gifted children. Interestingly, intellectual ability measured as IQ was negatively associated with salivary testosterone in both sexes. Similar results were found in our follow-up study showing significantly lower testosterone in gifted boys than controls (Ostatnikova et al. 2007).

Without access to prenatal testosterone it can be speculated that being exposed to higher prenatal testosterone in utero may lead to a lower postnatal set-up of the hypothalamo-pituitary-gonadal axis. This finding could also indicate later maturation of intellectually gifted children. It has been proposed that the hormonal changes responsible for the timing of puberty reflect the differences in cognitive abilities (Waber 1976). The late maturers were reported to score better in spatial tasks that individuals who matured early. This finding was confirmed later by others (Ray et al. 1981, Sanders and Soares 1986). There is a solid evidence that intellectually gifted children are born with atypical brains as a product of genes and their messengers - hormones in critical periods. There are several other unique neurobiological features present in the gifted children. For example, there is a trend toward increased right-hemisphere involvement in this population. Geschwind-Behan-Galaburda theory of cerebral dominance (1987) argued that higher than normal concentrations of testosterone in utero may inhibit the development of the left hemisphere while enhancing other areas, such as the right hemisphere (Geschwind and Galaburda 1985). The proposed consequences of this developmental disbalance is the ability to visualize problems individuals are working on and to translate those visual images into the abstract language of mathematics. According to this well-known theory, gifted children with exposure to higher testosterone in utero will 
also have non-standard hemispheric specialization and handedness but also higher risk of allergy. Our findings of higher allergy prevalence and lower percentage of right handedness in intellectually gifted children supported this hypothesis (Ostatnikova et al. 2002). Studies on mathematically gifted individuals confirmed the unique functional characteristic with bigger involvement of the right hemisphere in mental processing that would also indicate an effect of intrauterine testosterone on the right hemispheric development (O'Boyle et al. 1991). Testosterone concentration is not the only determinant of androgen signaling. The sensitivity of the androgen receptor has to be considered as well. Several studies examined the association between the CAG polymorphism in exon 1 of the androgen receptor gene and cognitive abilities. Lee with colleagues found no association between CAG repeat length and fluid intelligence in older men (Lee et al. 2010). Our study revealed a significantly lower number of CAG repeats in the AR gene in gifted boys in comparison with controls indicating stronger androgen signaling in this population. This could also explain why lower testosterone is found in gifted boys, for the overall androgen signaling it might be sufficient (Celec et al. 2009b, Celec et al. 2013).

The neurobiological basis of variation in intelligence remains unresolved. According to Catell's intelligence theory (Cattel, 1943) fluid intelligence is the pure general ability to discriminate and perceive relations between any fundaments. It is predominant in childhood and increases until adolescence. Crystalized intelligence refers to discriminatory habits long established in a particular field and culminates in adulthood. It is known that fluid intelligence depends on cognitive processes that are mediated most prominently by frontal lobes (Duncan et al. 2000, Duncan 2005). Frontal cortical regions are part of those neural networks that are under the influence of androgens including testosterone (Bramen et al. 2012). Gonadal steroids induce morphological changes in the neuronal system such as growth, morphological differentiation or programmed apoptosis of particular groups of neurons in topographically specific regions that contain androgen and/or estrogen receptors (MacLusky et al. 1997, MacLusky et al. 2006).

The effects of testosterone on brain structure and function are complex. Besides abovementioned metabolism of testosterone that might end in activation of estrogen rather than androgen receptors, the association between outcomes and testosterone concentrations is not linear. Tan and Tan (1998) proposed a curvilinear correlation between total testosterone and fluid intelligence in men and women. They studied the relationship between serum total testosterone and fluid intelligence in young men and women. As expected, there was no significant difference between average IQ of men and women. IQ tended to increase with testosterone levels in men, except at very high levels. The authors concluded that too low or too high testosterone concentrations may be disadvantageous for fluid intelligence. The non-linear nature of the association could explain the difficulties to reproduce the association as many scientists only look for linear correlations and not for complex interactions.

\section{Testosterone and specific cognitive abilities}

Adult men generally outperform women in spatial abilities (Linn and Petersen 1985). Especially, mental rotation shows a sex difference in favor of men. Even though some authors argue that contribution of androgens to human performance on mental rotation tasks may be limited to early organizational periods (Puts et al. 2010, Courvoisier et al. 2013), there is some evidence supporting the existence of the association between actual testosterone and mental rotation performance ( $\mathrm{O}^{\prime} \mathrm{Connor}$ et al. 2001, Alexander and Son 2007). Some studies have reported a positive relationship - the higher the testosterone concentration, the higher the performance (Hausmann et al. 2009), whereas other studies have found that the association follows an inverted U-shape with best performance at average testosterone concentrations (O'Connor et al. 2001). Again, this nonlinear association could lead to bias and misleading interpretations of results depending on the analysis used. So, it is unsurprisingly that some authors report also a negative correlation between mental rotation and testosterone (Vuoksimaa et al. 2012). An additional factor that increases the complexity of the issue is the genetic variability of the androgen sensitivity as described for mental rotation and androgen receptor gene in our study (Durdiakova et al. 2013).

Activational effects of gonadal hormones were studied by relying on naturally occurring biorhythms. Although not free from bias, the menstrual cycle provides a convenient method for studying specific cognitive performance in relation to fluctuation of actual testosterone concentrations. The mentioned bias might arise from fluctuating well-being of women during the 
menstrual cycle that might affect the performance in cognitive tests (Celec et al. 2011). Some studies confirmed curvilinear or U-shaped relationship between testosterone and spatial abilities (O'Connor et al. 2001). Shute (1983) found that females with the highest physiological androgen levels performed better in spatial cognition test than females with the lowest androgen levels, whereas males who had the highest androgen levels performed worse than males with the lowest androgen levels. Our research group has tested healthy men and women in reproductive age for mental rotation and spatial visualization. Performance in these two standardized tests were related to actual salivary testosterone concentrations, which reflected the bioavailable free fraction of this hormone (Celec et al. 2002, Ostatnikova et al. 2010). A negative relationship between testosterone and spatial performance was found in male subjects while a positive though only marginally significant relationship was observed in women. The best spatial performance was proposed in hormonally androgynous subjects. This was a proof of the U-shaped association between testosterone and specific cognitive abilities on an interindividual level. However, in the same study we have also shown association of the short term changes, as part of the infradian fluctuations in endogenous salivary testosterone, with spatial cognition in humans (Celec et al. 2009a). In men, an intraindividual increase of testosterone was associated with worse spatial performance in mental rotation test, a decrease of testosterone was accompanied by an improved spatial performance. In women, the opposite associations were found. These results support the hypothesis of activational effects of testosterone fluctuations during the menstrual cycle in women or the proposed infradian circatrigintan (e.g. with a period of approximately 30 days) cycle in men on spatial abilities and likely also other cognitive functions (Celec et al. 2003, Ostatnikova et al. 2010). Whether other biological rhythms of testosterone affect cognitive abilities or other brain functions is surprisingly unexplored. Even the widely known and accepted daily rhythm of testosterone has not been analyzed yet in relation to cognition (Reinberg et al. 1975, Guignard et al. 1980). Less surprisingly, neither the yearly, nor other less known infradian rhythms of testosterone were tested as determinants of cognitive abilities (Celec et al. 2007b, Smith et al. 2013). The reason might be simply the demanding design of the research studies. As the rhythms can be detected only by analyzing testosterone in long time series, sampling is one major issue. The other is the need for repeated testing of cognitive abilities which might bias the outcome as most of the tests are affected by learning (Tao et al. 2019).

Despite contradictory results, partially due to different analysis used, the majority of studies indicate that the association between testosterone and cognitive, especially spatial abilities is curvilinear and sexdependent. In women, higher testosterone is associated with better mental rotation; in men, lower testosterone is associated with better performance. This seems to be true for both, actual and prenatal testosterone (Grimshaw et al. 1995, Moffat and Hampson 1996). Despite intensive research and numerous publications to describe how exogenous testosterone affects cognition and emotions is very difficult if not impossible. Most of the published literature agrees on the fact that testosterone besides its anxiolytic and anti-depressant effect improves spatial abilities (Cherrier et al. 2001, Cherrier et al. 2005, Burkitt et al. 2007, Pintzka et al. 2016). Nevertheless, this conclusion is far too simplistic, because many other endocrine, genetic and other factors influence the final cognitive outcome.

\section{Testosterone and autism spectrum disorder}

Autism spectrum disorders (ASD) are a set of heterogeneous neurodevelopmental conditions, characterrized by early-onset difficulties in social reciprocal communication and restricted, repetitive behavior and interests. Child autism, atypical autism and Asperger's syndrome are included under the umbrella term ASD reflecting DSM 5 (2013) and IDC 11 (2019). The worldwide population prevalence is about $1 \%$, but the male prevalence is four times higher than female (Lai et al. 2014). Although autism is neurodevelopmental disorder biologic markers are still not available. Heritability of ASD is high as is the number of genes found to be in association with the ASD (Sklar et al. 2013, Gaugler et al. 2014, Colvert et al. 2015, Sandin et al. 2017). Disruption of the developmental trajectory can be caused by a combination of genetic and epigenetic factors. The gene - environment interactions are difficult to study, but they probably affect neurogenesis, neuronal apoptosis as well as synaptogenesis and synaptic pruning resulting into the impairment in neuronal connectivity and function. A two-hit model has been developed involving prenatal or early postnatal neuroinflammation and male sex - their interactions could lead to, or increase 
the risk of autistic behavior (Carlezon et al. 2019). The three-hit model includes in addition the genetic factors causal mutations or associated copy number variations and/or single nucleotide polymorphisms (Rylaarsdam and Guemez-Gamboa 2019). This model has been generalized besides ASD for related neurodevelopmental disorders such as schizophrenia or attention deficit/hyperactivity disorder (Ardalan et al. 2019). It is, however, possible that the hits - causes are interlinked. At least in some periods of development inflammation in the cerebellum has been shown to induce expression and activity of aromatase and, thus, increase local estradiol synthesis (Hoffman et al. 2016, Wright et al. 2019).

It has been hypothesized that autism may be the result of disrupted hormonal balance during prenatal developmental periods (Baron-Cohen 2002, Gore et al. 2014). Considering gender differences in cognitive profile in normal population, typical male cognitive profile is described as less emotional and more systematic. On the other hand, females are more emotional and less systematic, cognitive profile of ASD patients is supposed to be more systematic and less empathic than in males from normal population (BaronCohen et al. 2011). It is, thus, logical that testosterone as a male sex hormone organizing the brain structure is suggested to play a role in the pathogenesis of ASD and to be responsible for the extreme male brain characteristics in autism (Baron-Cohen et al. 2011). The so called extreme-male brain theory developed by BaronCohen predicts a stronger testosterone exposure during prenatal development in autistic subjects, which is potentially testable by the analysis of the 2D:4D digit ratio (Baron-Cohen 2002, Baron-Cohen 2005, Krajmer et al. 2011). In our large unpublished animal experiment we have not proved the theory, others have shown that prenatal letrozole as an aromatase blocker can induce autistic-like behavior in rats (Xu et al. 2015). It is possible that the observations of higher testosterone in the amniotic fluid of children with autistic phenotype and abovementioned experimental results are explainable by indirect associations via modulation of aromatase activity or via dysregulation of the luteinizing hormone (Auyeung et al. 2009a).

Not only prenatal, but also postnatal testosterone levels seem to be higher in ASD children (Knickmeyer et al. 2006, Knickmeyer and Baron-Cohen 2006). Our research group confirmed higher testosterone concentrations in prepubertal boys with ASD in comparison to their peers from general healthy population
(Ostatnikova et al. 2016). As aggression is generally more prevalent in males, testosterone was studied in relation to aggressive behavior (Constantino et al. 1993, Durdiakova et al. 2011). In ASD boys a positive correlation was described between explosive aggression and androgenic activity (Tordjman et al. 1997, Pivovarciova et al. 2014, Pivovarciova et al. 2015). In accordance with the notion that testosterone acts via androgen receptor several studies attempted to examine its sensitivity. Henningsson et al. (2009) confirmed a lower number of CAG repeats in the androgen receptor gene in ASD subjects in comparison with controls implying stronger androgen signaling (Henningsson et al. 2009). In comparison with the control population the higher transactivational activity of the androgen receptor might lead to increased androgenic signaling in ASD individuals despite only slightly higher or comparable circulating testosterone concentrations.

In addition to the androgen receptor, genetic variability in the main steroid converting enzymes aromatase, converting testosterone to estradiol and 5-alpha reductase, converting testosterone to a more potent androgen dihydrotestosterone - seems to belong to the factors determining interindividual variability of androgen-related brain functions and dysfunctions. Schmidtova et al. (2010) revealed differences in genotype distribution of alleles of the SRD5A2 gene for 5-alpha reductase and CYP19 gene for aromatase between the groups (Schmidtova et al. 2010). The alleles that have a known functional consequences and are more common in ASD children increase the androgen signaling, for example via higher biochemical activity of $5 \alpha$-reductase leading to increased concentrations of dihydrotestosterone that strongly activates the androgen receptor (Makridakis et al. 1999). These findings indicate that both, genetic and epigenetic factors affect the role of steroids in autism pathogenesis. In addition, the extreme male brain in autism is probably not strictly caused by higher testosterone but also other steroid hormones with androgen activity might be involved. The overall fetal steroidogenic activity in autism was reported to be higher and might be important as an epigenetic fetal programming mechanism (Baron-Cohen et al. 2015).

\section{Conclusion and future outlook}

From the evolutionary perspective testosterone is a precursor of estradiol, dihydrotestoterone and other metabolites rather than a hormone per se (Callard et al. 
2011, Durdiakova et al. 2011). Studying its effects is, thus, complicated, biased and potentially misleading, since the activation of androgen and estrogen receptors in the particular tissues should be the true modulation factors, not the testosterone concentration in blood plasma (Hodosy et al. 2012b, Hodosy et al. 2012c). In experimental studies, gonadectomy and subsequent testosterone supplementation are often used (Domonkos et al. 2018). Testicles are, however, much more than a plain factory for the production of testosterone, and administration of exogenous testosterone leads to a variable outcome depending on the enzymatic and endocrine context of the target tissue (Nathan et al. 2001, Ghosh et al. 2018). Theoretically, genetic models could solve some of these issues, but the dynamic changes during the development both, in the metabolism and the recognition of steroids make these models less informative.

The intense and long-lasting research on testosterone and the brain has brought insights into many aspects of physiology, but also into pathogenesis of diseases and, thus, into clinical medicine far beyond basic clinical endocrinology (Petering and Brooks 2017). The road is, however, not ending here. Despite all the scientific insight, the practical interventional applications of modulating androgen signaling and metabolism are limited. Numerous experiments and studies were done on testosterone and autism, but we still do not know its true role in this mysterious disorder and neither letrozole, nor flutamide, not any other androgen-modulating drug has been tested in ASD. Future research should also look into the association of androgen-related cognitive functions and dysfunctions with testosterone metabolites and regulators, including gonadotropin releasing hormone and luteinizing hormone (Blair et al. 2015, Morote et al. 2017, Bhatta et al. 2018). All of these undergo also ultradian rhythms that are largely unexplored in relation to any physiological parameters including cognitive abilities (Albertsson-Wikland et al. 1997, Beaven et al. 2010). Lateralization of brain structure or functions was clearly demonstrated to be causally related to prenatal testosterone (Beking et al. 2018). But the underlying mechanisms likely including the non-genomic pathways should be the subject of studies in the near future.

\section{Conflict of Interest}

There is no conflict of interest.

\section{Acknowledgements}

This research was funded by the Slovak Research and Development Agency (APVV - Agentúra na Podporu Výskumu a Vývoja) grant numbers APVV 15-0085, APVV 15-0045.

\section{References}

ALBERTSSON-WIKLAND K, ROSBERG S, LANNERING B, DUNKEL L, SELSTAM G, NORJAVAARA E: Twenty-four-hour profiles of luteinizing hormone, follicle-stimulating hormone, testosterone, and estradiol levels: a semilongitudinal study throughout puberty in healthy boys. J Clin Endocrinol Metab 82: 541-549, 1997. https://doi.org/10.1210/jcem.82.2.3778

ALEXANDER GM, SON T: Androgens and eye movements in women and men during a test of mental rotation ability. Horm Behav 52: 197-204, 2007. https://doi.org/10.1016/j.yhbeh.2007.01.011

ARDALAN M, CHUMAK T, VEXLER Z, MALLARD C: Sex-dependent effects of perinatal inflammation on the brain: Implication for neuro-psychiatric disorders. Int J Mol Sci 20: 2270, 2019. https://doi.org/10.3390/ijms20092270

ARNOLD AP: The organizational-activational hypothesis as the foundation for a unified theory of sexual differentiation of all mammalian tissues. Horm Behav 55: 570-578, 2009. https://doi.org/10.1016/j.yhbeh.2009.03.011

ARNOLD AP, BREEDLOVE SM: Organizational and activational effects of sex steroids on brain and behavior: a reanalysis. Horm Behav 19: 469-498, 1985. https://doi.org/10.1016/0018-506X(85)90042-X

AUYEUNG B, BARON-COHEN S, ASHWIN E, KNICKMEYER R, TAYLOR K, HACKETT G: Fetal testosterone and autistic traits. Br J Psychol 100: 1-22, 2009a. https://doi.org/10.1348/000712608X311731

AUYEUNG B, BARON-COHEN S, ASHWIN E, KNICKMEYER R, TAYLOR K, HACKETT G, HINES M: Fetal testosterone predicts sexually differentiated childhood behavior in girls and in boys. Psychol Sci 20: 144-148, 2009b. https://doi.org/10.1111/j.1467-9280.2009.02279.x 
AUYEUNG B, BARON-COHEN S, ASHWIN E, KNICKMEYER R, TAYLOR K, HACKETT G, HINES M: Fetal testosterone predicts sexually differentiated childhood behavior in girls and in boys. Psychol Sci 20: 144-148, 2009c. https://doi.org/10.1111/j.1467-9280.2009.02279.x

BARBIERI RL: The endocrinology of the menstrual cycle. Methods Mol Biol 1154: 145-169, 2014. https://doi.org/10.1007/978-1-4939-0659-8 7

BARON-COHEN S: The extreme male brain theory of autism. Trends Cogn Sci 6: 248-254, 2002. https://doi.org/10.1016/S1364-6613(02)01904-6

BARON-COHEN S: Testing the extreme male brain (EMB) theory of autism: let the data speak for themselves. Cogn Neuropsychiatry 10: 77-81, 2005. https://doi.org/10.1080/13546800344000336

BARON-COHEN S, AUYEUNG B, NORGAARD-PEDERSEN B, HOUGAARD DM, ABDALLAH MW, MELGAARD L, COHEN AS, CHAKRABARTI B, RUTA L, LOMBARDO MV: Elevated fetal steroidogenic activity in autism. Mol Psychiatry 20: 369-376, 2015. https://doi.org/10.1038/mp.2014.48

BARON-COHEN S, LOMBARDO MV, AUYEUNG B, ASHWIN E, CHAKRABARTI B, KNICKMEYER R: Why are autism spectrum conditions more prevalent in males? PLoS Biol 9: e1001081, 2011. https://doi.org/10.1371/journal.pbio.1001081

BEATON AA, RUDLING N, KISSLING C, TAURINES R, THOME J: Digit ratio (2D:4D), salivary testosterone, and handedness. Laterality 16: 136-155, 2011. https://doi.org/10.1080/13576500903410369

BEAVEN CM, INGRAM JR, GILL ND, HOPKINS WG: Ultradian rhythmicity and induced changes in salivary testosterone. Eur J Appl Physiol 110: 405-413, 2010. https://doi.org/10.1007/s00421-010-1518-3

BEKING T, GEUZE RH, VAN FAASSEN M, KEMA IP, KREUKELS BPC, GROOTHUIS TGG: Prenatal and pubertal testosterone affect brain lateralization. Psychoneuroendocrinology 88: 78-91, 2018. https://doi.org/10.1016/j.psyneuen.2017.10.027

BENBOW CP: Sex differences in mathematical reasoning ability in intellectually talented preadolescents: Their nature, effects, and possible causes. Behavioral and Brain Sciences 11: 169-232, 1988. https://doi.org/10.1017/S0140525X00049244

BHATTA S, BLAIR JA, CASADESUS G: Luteinizing hormone involvement in aging female cognition: Not all is estrogen loss. Front Endocrinol (Lausanne) 9: 544, 2018. https://doi.org/10.3389/fendo.2018.00544

BLAIR JA, BHATTA S, MCGEE H, CASADESUS G: Luteinizing hormone: Evidence for direct action in the CNS. Horm Behav 76: 57-62, 2015. https://doi.org/10.1016/j.yhbeh.2015.06.020

BRAMEN JE, HRANILOVICH JA, DAHL RE, CHEN J, ROSSO C, FORBES EE, DINOV ID, WORTHMAN CM, SOWELL ER: Sex matters during adolescence: testosterone-related cortical thickness maturation differs between boys and girls. PLoS One 7: e33850, 2012. https://doi.org/10.1371/journal.pone.0033850

BURKITT J, WIDMAN D, SAUCIER DM: Evidence for the influence of testosterone in the performance of spatial navigation in a virtual water maze in women but not in men. Horm Behav 51: 649-654, 2007. https://doi.org/10.1016/j.yhbeh.2007.03.007

CALLARD GV, TARRANT AM, NOVILLO A, YACCI P, CIACCIA L, VAJDA S, CHUANG GY, KOZAKOV D, GREYTAK SR, SAWYER S, HOOVER C, COTTER KA: Evolutionary origins of the estrogen signaling system: insights from amphioxus. J Steroid Biochem Mol Biol 127: 176-188, 2011. https://doi.org/10.1016/j.jsbmb.2011.03.022

CARLEZON WA, KIM W, MISSIG G, FINGER BC, LANDINO SM, ALEXANDER AJ, MOKLER EL, ROBBINS JO, LI Y, BOLSHAKOV VY, MCDOUGLE CJ, KIM K-S: Maternal and early postnatal immune activation produce sex-specific effects on autism-like behaviors and neuroimmune function in mice. Sci Rep 9: 16928, 2019. https://doi.org/10.1038/s41598-019-53294-z

CELEC P, MESEZNIKOV G, OSTATNIKOVA D, HODOSY J: Changes in well-being but not in spatial ability across the menstrual cycle. Biol Rhythm Res 42: 255-259, 2011. https://doi.org/10.1080/09291016.2010.513524

CELEC P, OSTANIKOVA D, SKOKNOVA M, HODOSY J, PUTZ Z, KUDELA M: Salivary sex hormones during the menstrual cycle. Endocr J 56: 521-523, 2009a. https://doi.org/10.1507/endocrj.K09E-020

CELEC P, OSTATNIKOVA D, HODOSY J: On the effects of testosterone on brain behavioral functions. Front Neurosci 9: 12, 2015. https://doi.org/10.3389/fnins.2015.00012 
CELEC P, OSTATNIKOVA D, HODOSY J, PUTZ Z, KUDELA M: Increased one week soybean consumption affects spatial abilities but not sex hormone status in men. Int J Food Sci Nutr 58: 424-428, 2007 a. https://doi.org/10.1080/09637480701253490

CELEC P, OSTATNIKOVA D, HODOSY J, SKOKNOVA M, PUTZ Z, KUDELA M: Infradian dynamics and variability of salivary testosterone in men and women. Biol Rhythm Res 38: 367-372, $2007 \mathrm{~b}$. https://doi.org/10.1080/09291010600981797

CELEC P, OSTATNIKOVA D, HOLESOVA Z, MINARIK G, FICEK A, KELEMENOVA S, PUTZ Z, KUDELA M: Spatial abilities in prepubertal intellectually gifted boys and genetic polymorphisms related to testosterone metabolism. J Psychophysiology 23: 1-6, 2009b. https://doi.org/10.1027/0269-8803.23.1.1

CELEC P, OSTATNIKOVA D, PUTZ Z, HODOSY J, BURSKY P, STARKA L, HAMPL R, KUDELA M: Circatrigintan cycle of salivary testosterone in human male. Biol Rhythm Res 34: 305-315, 2003. https://doi.org/10.1076/brhm.34.3.305.18807

CELEC P, OSTATNIKOVA D, PUTZ Z, KUDELA M: The circalunar cycle of salivary testosterone and the visualspatial performance. Bratisl Lek Listy 103: 59-69, 2002.

CELEC P, TRETINAROVA D, MINARIK G, FICEK A, SZEMES T, LAKATOSOVA S, SCHMIDTOVA E, TURNA J, KADASI L, OSTATNIKOVA D: Genetic polymorphisms related to testosterone metabolism in intellectually gifted boys. PLoS One 8: e54751, 2013. https://doi.org/10.1371/journal.pone.0054751

CHERRIER MM, ASTHANA S, PLYMATE S, BAKER L, MATSUMOTO AM, PESKIND E, RASKIND MA, BRODKIN K, BREMNER W, PETROVA A, LATENDRESSE S, CRAFT S: Testosterone supplementation improves spatial and verbal memory in healthy older men. Neurology 57: 80-88, 2001. https://doi.org/10.1212/WNL.57.1.80

CHERRIER MM, MATSUMOTO AM, AMORY JK, ASTHANA S, BREMNER W, PESKIND ER, RASKIND MA, CRAFT S: Testosterone improves spatial memory in men with Alzheimer disease and mild cognitive impairment. Neurology 64: 2063-2068, 2005. https://doi.org/10.1212/01.WNL.0000165995.98986.F1

CHOE MS, ORTIZ-MANTILLA S, MAKRIS N, GREGAS M, BACIC J, HAEHN D, KENNEDY D, PIENAAR R, CAVINESS VS, JR., BENASICH AA, GRANT PE: Regional infant brain development: an MRI-based morphometric analysis in 3 to 13 month olds. Cereb Cortex 23: 2100-2117, 2013. https://doi.org/10.1093/cercor/bhs197

CHURA LR, LOMBARDO MV, ASHWIN E, AUYEUNG B, CHAKRABARTI B, BULLMORE ET, BARONCOHEN S: Organizational effects of fetal testosterone on human corpus callosum size and asymmetry. Psychoneuroendocrinology 35: 122-132, 2010. https://doi.org/10.1016/j.psyneuen.2009.09.009

COHEN-BENDAHAN CC, BUITELAAR JK, VAN GOOZEN SH, ORLEBEKE JF, COHEN-KETTENIS PT: Is there an effect of prenatal testosterone on aggression and other behavioral traits? A study comparing same-sex and opposite-sex twin girls. Horm Behav 47: 230-237, 2005. https://doi.org/10.1016/j.yhbeh.2004.10.006

COLLAER ML, HINES M: Human behavioral sex differences: a role for gonadal hormones during early development? Psychol Bull 118: 55-107, 1995. https://doi.org/10.1037/0033-2909.118.1.55

COLVERT E, TICK B, MCEWEN F, STEWART C, CURRAN SR, WOODHOUSE E, GILLAN N, HALLETT V, LIETZ S, GARNETT T, RONALD A, PLOMIN R, RIJSDIJK F, HAPPE F, BOLTON P: Heritability of autism spectrum disorder in a UK population-based twin sample. JAMA Psychiatry 72: 415-423, 2015. https://doi.org/10.1001/jamapsychiatry.2014.3028

CONNOLLY PB, RESKO JA: Prenatal testosterone differentiates brain regions controlling gonadotropin release in guinea pigs. Biol Reprod 51: 125-130, 1994. https://doi.org/10.1095/biolreprod51.1.125

CONSTANTINO JN, GROSZ D, SAENGER P, CHANDLER DW, NANDI R, EARLS FJ: Testosterone and aggression in children. J Am Acad Child Adolesc Psychiatry 32: 1217-1222, 1993. https://doi.org/10.1097/00004583199311000-00015

COURVOISIER DS, RENAUD O, GEISER C, PASCHKE K, GAUDY K, JORDAN K: Sex hormones and mental rotation: an intensive longitudinal investigation. Horm Behav 63: 345-351, 2013. https://doi.org/10.1016/j.yhbeh.2012.12.007

DE LACOSTE MC, HORVATH DS, WOODWARD DJ: Possible sex differences in the developing human fetal brain. J Clin Exp Neuropsychol 13: 831-846, 1991. https://doi.org/10.1080/01688639108405101 
DEARY IJ, STRAND S, SMITH P, FERNANDEZ C: Intelligence and educational achievement. Intelligence 35: 13-21, 2007. https://doi.org/10.1016/j.intell.2006.02.001

DEARY IJ: Intelligence. Curr Biol 23: R673-R676, 2013. https://doi.org/10.1016/j.cub.2013.07.021

DEONI SCL, DEAN DC 3RD, REMER J, DIRKS H, O'MUIRCHEARTAIGH J: Cortical maturation and myelination in healthy toddlers and young children. NeuroImage 115: 147-161, 2015. https://doi.org/10.1016/j.neuroimage.2015.04.058

DIPIETRO JA, VOEGTLINE KM: The gestational foundation of sex differences in development and vulnerability. Neuroscience 342: 4-20, 2017. https://doi.org/10.1016/j.neuroscience.2015.07.068

DOMONKOS E, BORBELYOVA V, CSONGOVA M, BOSY M, KACMAROVA M, OSTATNIKOVA D, HODOSY J, CELEC P: Sex differences and sex hormones in anxiety-like behavior of aging rats. Horm Behav 93: 159-165, 2017a. https://doi.org/10.1016/j.yhbeh.2017.05.019

DOMONKOS E, BORBELYOVA V, KOLATOROVA L, CHLUPACOVA T, OSTATNIKOVA D, HODOSY J, STARKA L, CELEC P: Sex differences in the effect of prenatal testosterone exposure on steroid hormone production in adult rats. Physiol Res 66 (Suppl 3): S367-S374, 2017b. https://doi.org/10.33549/physiolres.933722

DOMONKOS E, HODOSY J, OSTATNIKOVA D, CELEC P: On the role of testosterone in anxiety-like behavior across life in experimental rodents. Front Endocrinol (Lausanne) 9: 441, 2018. https://doi.org/10.3389/fendo.2018.00441

DUNCAN J: Frontal lobe function and general intelligence: why it matters. Cortex 41: 215-217, 2005. https://doi.org/10.1016/S0010-9452(08)70896-7

DUNCAN J, SEITZ RJ, KOLODNY J, BOR D, HERZOG H, AHMED A, NEWELL FN, EMSLIE H: A neural basis for general intelligence. Science 289: 457-460, 2000. https://doi.org/10.1126/science.289.5478.457

DURDIAKOVA J, CELEC P, LAZNIBATOVA J, MINARIK G, LAKATOSOVA S, KUBRANSKA A, OSTATNIKOVA D: Differences in salivary testosterone, digit ratio and empathy between intellectually gifted and control boys. Intelligence 48: 76-84, 2015. https://doi.org/10.1016/j.intell.2014.11.002

DURDIAKOVA J, LAKATOSOVA S, KUBRANSKA A, LAZNIBATOVA J, FICEK A, OSTATNIKOVA D, CELEC P: Mental rotation in intellectually gifted boys is affected by the androgen receptor CAG repeat polymorphism. Neuropsychologia 51: 1693-1698, 2013. https://doi.org/10.1016/j.neuropsychologia.2013.05.016

DURDIAKOVA J, OSTATNIKOVA D, CELEC P: Testosterone and its metabolites - modulators of brain functions. Acta Neurobiol Exp (Wars) 71: 434-454, 2011.

FILOVA B, DOMONKOS E, BORBELYOVA V, BABICKOVA J, TOTHOVA L, OSTATNIKOVA D, CELEC P, HODOSY J: Does the non-genomic effect of testosterone on social anxiety require the presence of a classical steroid receptor? Acta Neurobiol Exp (Wars) 75: 457-461, $2015 \mathrm{a}$.

FILOVA B, MALINOVA M, BABICKOVA J, TOTHOVA L, OSTATNIKOVA D, CELEC P, HODOSY J: Effects of testosterone and estradiol on anxiety and depressive-like behavior via a non-genomic pathway. Neuroscience Bulletin 31: 288-296, 2015b. https://doi.org/10.1007/s12264-014-1510-8

FILOVA B, OSTATNIKOVA D, CELEC P, HODOSY J: The effect of testosterone on the formation of brain structures. Cells Tissues Organs 197: 169-177, 2013. https://doi.org/10.1159/000345567

FLANNERY KA, LIEDERMAN J, DALY L, SCHULTZ J: Male prevalence for reading disability is found in a large sample of black and white children free from ascertainment bias. J Int Neuropsychol Soc 6: 433-442, 2000. https://doi.org/10.1017/S1355617700644016

GAUGLER T, KLEI L, SANDERS SJ, BODEA CA, GOLDBERG AP, LEE AB, MAHAJAN M, MANAA D, PAWITAN Y, REICHERT J, RIPKE S, SANDIN S: Most genetic risk for autism resides with common variation. Nat Genet 46: 881-885, 2014. https://doi.org/10.1038/ng.3039

GESCHWIND N, GALABURDA AM: Cerebral lateralization. Biological mechanisms, associations, and pathology: I. A hypothesis and a program for research. Arch Neurol 42: 428-459, 1985. https://doi.org/10.1001/archneur.1985.04060050026008

GHOSH D, EGBUTA C, LO J: Testosterone complex and non-steroidal ligands of human aromatase. J Steroid Biochem Mol Biol 181: 11-19, 2018. https://doi.org/10.1016/j.jsbmb.2018.02.009 
GILMORE JH, LIN W, PRASTAWA MW, LOONEY CB, VETSA YS, KNICKMEYER RC, EVANS DD, SMITH JK, HAMER RM, LIEBERMAN JA, GERIG G: Regional gray matter growth, sexual dimorphism, and cerebral asymmetry in the neonatal brain. J Neurosci 27: 1255-1260, 2007. https://doi.org/10.1523/JNEUROSCI.3339-06.2007

GOEL N, BALE TL: Organizational and activational effects of testosterone on masculinization of female physiological and behavioral stress responses. Endocrinology 149: 6399-6405, 2008. https://doi.org/10.1210/en.2008-0433

GORE AC, MARTIEN KM, GAGNIDZE K, PFAFF D: Implications of prenatal steroid perturbations for neurodevelopment, behavior, and autism. Endocr Rev 35: 961-991, 2014. https://doi.org/10.1210/er.2013-1122

GOUCHIE C, KIMURA D: The relationship between testosterone levels and cognitive ability patterns. Psychoneuroendocrinology 16: 323-334, 1991. https://doi.org/10.1016/0306-4530(91)90018-O

GREENLAND KJ, BEILIN J, CASTRO J, VARGHESE PN, ZAJAC JD: Polymorphic CAG repeat length in the androgen receptor gene and association with neurodegeneration in a heterozygous female carrier of Kennedy's disease. J Neurol 251: 35-41, 2004. https://doi.org/10.1007/s00415-004-0266-X

GRIMSHAW GM, SITARENIOS G, FINEGAN JA: Mental rotation at 7 years: relations with prenatal testosterone levels and spatial play experiences. Brain Cogn 29: 85-100, 1995. https://doi.org/10.1006/brcg.1995.1269

GUIGNARD MM, PESQUIES PC, SERRURIER BD, MERINO DB, REINBERG AE: Circadian rhythms in plasma levels of cortisol, dehydroepiandrosterone, delta 4-androstenedione, testosterone and dihydrotestosterone of healthy young men. Acta Endocrinol (Copenh) 94: 536-545, 1980. https://doi.org/10.1530/acta.0.0940536

GUR RC, TURETSKY BI, MATSUI M, YAN M, BILKER W, HUGHETT P, GUR RE: Sex differences in brain gray and white matter in healthy young adults: Correlations with cognitive performance. J Neurosci 19: 4065-4072, 1999. https://doi.org/10.1523/JNEUROSCI.19-10-04065.1999

HARDEN KP, KRETSCH N, TACKETT JL, TUCKER-DROB EM: Genetic and environmental influences on testosterone in adolescents: evidence for sex differences. Dev Psychobiol 56: 1278-1289, 2014. https://doi.org/10.1002/dev.21207

HAUSMANN M, SCHOOFS D, ROSENTHAL HE, JORDAN K: Interactive effects of sex hormones and gender stereotypes on cognitive sex differences--a psychobiosocial approach. Psychoneuroendocrinology 34: 389-401, 2009. https://doi.org/10.1016/i.psyneuen.2008.09.019

HEDGES LV, NOWELL A: Sex differences in mental test scores, variability, and numbers of high-scoring individuals. Science 269: 41-45, 1995. https://doi.org/10.1126/science.7604277

HENNINGSSON S, JONSSON L, LJUNGGREN E, WESTBERG L, GILLBERG C, RASTAM M, ANCKARSATER H, NYGREN G, LANDEN M, THURESSON K, BETANCUR C, LEBOYER M, GILLBERG C, ERIKSSON E, MELKE J: Possible association between the androgen receptor gene and autism spectrum disorder. Psychoneuroendocrinology 34: 752-761, 2009. https://doi.org/10.1016/j.psyneuen.2008.12.007

HILLEKE EHP, PEGGY TC-K, NEELTJE EMVH, JISKA SP, RACHEL GHB, WIEPKE C, HUGO GS, LOUIS JGG, RENÉ SK: Changing your sex changes your brain: influences of testosterone and estrogen on adult human brain structure. Eur J Endocrinol 155 (Suppl 1): S107-S114, 2006. https://doi.org/10.1530/eje.1.02248

HILLMER AM, HANNEKEN S, RITZMANN S, BECKER T, FREUDENBERG J, BROCKSCHMIDT FF, FLAQUER A, FREUDENBERG-HUA Y, JAMRA RA, METZEN C, HEYN U, SCHWEIGER N, BETZ RC, BLAUMEISER B, HAMPE J, SCHREIBER S, SCHULZE TG, HENNIES HC, SCHUMACHER J, PROPPING P, RUZICKA T, CICHON S, WIENKER TF, KRUSE R, NOTHEN MM: Genetic variation in the human androgen receptor gene is the major determinant of common early-onset androgenetic alopecia. Am J Hum Genet 77: 140-148, 2005. https://doi.org/10.1086/431425

HINES M: Prenatal testosterone and gender-related behaviour. Eur J Endocrinol 155 (Suppl 1): S115-S121, 2006. https://doi.org/10.1530/eje.1.02236

HIORT O: The differential role of androgens in early human sex development. BMC Medicine 11: $152,2013$. https://doi.org/10.1186/1741-7015-11-152

HODOSY J, OSTATNIKOVA D, KUDELA M, CELEC P: Behavioral effects of physical exercise and exogenous testosterone in male rats. Neurophysiology 44: 409-413, 2012a. https://doi.org/10.1007/s11062-012-9312-y 
HODOSY J, OSTATNIKOVA D, RILJAK V, MYSLIVECEK J, CELEC P: The effect of rapid and depot testosterone and estradiol on spatial performance in water maze. Cent Eur J Biol 7: 596-602, 2012 b. https://doi.org/10.2478/s11535-012-0046-Z

HODOSY J, ZELMANOVA D, MAJZUNOVA M, FILOVA B, MALINOVA M, OSTATNIKOVA D, CELEC P: The anxiolytic effect of testosterone in the rat is mediated via the androgen receptor. Pharmacol Biochem Behav 102: 191-195, 2012c. https://doi.org/10.1016/j.pbb.2012.04.005

HOFFMAN JF, WRIGHT CL, MCCARTHY MM: A critical period in Purkinje cell development is mediated by local estradiol synthesis, disrupted by inflammation, and has enduring consequences only for males. J Neurosci 36 : 10039-10049, 2016. https://doi.org/10.1523/JNEUROSCI.1262-16.2016

HYDE JS, FENNEMA E, LAMON SJ: Gender differences in mathematics performance: a meta-analysis. Psychol Bull 107: 139-155, 1990. https://doi.org/10.1037/0033-2909.107.2.139

INGALHALIKAR M, SMITH A, PARKER D, SATTERTHWAITE TD, ELLIOTT MA, RUPAREL K, HAKONARSON H, GUR RE, GUR RC, VERMA R: Sex differences in the structural connectome of the human brain. Proc Natl Acad Sci U S A 111: 823-828, 2014. https://doi.org/10.1073/pnas.1316909110

IRVINE RA, MA H, YU MC, ROSS RK, STALLCUP MR, COETZEE GA: Inhibition of p160-mediated coactivation with increasing androgen receptor polyglutamine length. Hum Mol Genet 9: 267-274, 2000. https://doi.org/10.1093/hmg/9.2.267

IVELL R, ANAND-IVELL R, MORLEY SD: Endocrinology of the Fetal Testis. In: Endocrinology of the Testis and Male Reproduction. Simoni M, Huhtaniemi IT (eds), Cham: Springer International Publishing, 2017, pp 245-272. https://doi.org/10.1007/978-3-319-44441-3 7

JOHNSON W, CAROTHERS A, DEARY IJ: Sex differences in variability in general intelligence: a new look at the old question. Perspect Psychol Sci 3: 518-531, 2008. https://doi.org/10.1111/j.1745-6924.2008.00096.x

KNICKMEYER R, BARON-COHEN S, FANE BA, WHEELWRIGHT S, MATHEWS GA, CONWAY GS, BROOK CG, HINES M: Androgens and autistic traits: A study of individuals with congenital adrenal hyperplasia. Horm Behav 50: 148-153, 2006. https://doi.org/10.1016/j.yhbeh.2006.02.006

KNICKMEYER R, BARON-COHEN S, RAGGATT P, TAYLOR K: Foetal testosterone, social relationships, and restricted interests in children. J Child Psychol Psychiatry 46: 198-210, 2005. https://doi.org/10.1111/j.14697610.2004.00349.x

KNICKMEYER RC, BARON-COHEN S: Fetal testosterone and sex differences in typical social development and in autism. J Child Neurol 21: 825-845, 2006. https://doi.org/10.1177/08830738060210101601

KOOLSCHIJN PC, CRONE EA: Sex differences and structural brain maturation from childhood to early adulthood. Dev Cogn Neurosci 5: 106-118, 2013. https://doi.org/10.1016/j.den.2013.02.003

KRAJMER P, SPAJDEL M, KUBRANSKA A, OSTATNIKOVA D: 2D:4D finger ratio in Slovak autism spectrum disorder population. Bratisl Lek Listy 112: 377-379, 2011.

LAI M-C, LOMBARDO MV, BARON-COHEN S: Autism. Lancet 383: 896-910, 2014. https://doi.org/10.1016/S01406736(13)61539-1

LEE DM, ULUBAEV A, TAJAR A, PYE SR, PENDLETON N, PURANDARE N, O'NEILL TW, O'CONNOR DB, LABRIE F, PLATT H, PAYNE D, BARTFAI G, BOONEN S, CASANUEVA FF, FINN JD, FORTI G, GIWERCMAN A, HAN TS, HUHTANIEMI IT, KULA K, LEAN ME, PUNAB M, SILMAN AJ, VANDERSCHUEREN D, WU FC: Endogenous hormones, androgen receptor CAG repeat length and fluid cognition in middle-aged and older men: results from the European Male Ageing Study. Eur J Endocrinol 162: 1155-1164, 2010. https://doi.org/10.1530/EJE-09-0970

LIEDERMAN J, KANTROWITZ L, FLANNERY K: Male vulnerability to reading disability is not likely to be a myth: a call for new data. J Learn Disabil 38: 109-129, 2005. https://doi.org/10.1177/00222194050380020201

LINN MC, PETERSEN AC: Emergence and characterization of sex differences in spatial ability: a meta-analysis. Child Dev 56: 1479-1498, 1985. https://doi.org/10.2307/1130467

LOMBARDO MV, ASHWIN E, AUYEUNG B, CHAKRABARTI B, TAYLOR K, HACKETT G, BULLMORE ET, BARON-COHEN S: Fetal testosterone influences sexually dimorphic gray matter in the human brain. J Neurosci 32: 674-680, 2012. https://doi.org/10.1523/JNEUROSCI.4389-11.2012 
LOSECAAT VERMEER AB, RIECANSKY I, EISENEGGER C: Competition, testosterone, and adult neurobehavioral plasticity. Prog Brain Res 229: 213-238, 2016. https://doi.org/10.1016/bs.pbr.2016.05.004

LUDERS E, TOGA AW: Sex differences in brain anatomy. Prog Brain Res 186: 3-12, 2010. https://doi.org/10.1016/B978-0-444-53630-3.00001-4

MACLUSKY NJ, BOWLBY DA, BROWN TJ, PETERSON RE, HOCHBERG RB: Sex and the developing brain: suppression of neuronal estrogen sensitivity by developmental androgen exposure. Neurochem Res 22: 1395-1414, 1997. https://doi.org/10.1023/A:1022027408234

MACLUSKY NJ, HAJSZAN T, PRANGE-KIEL J, LERANTH C: Androgen modulation of hippocampal synaptic plasticity. Neuroscience 138: 957-965, 2006. https://doi.org/10.1016/j.neuroscience.2005.12.054

MANNING JT, BARLEY L, WALTON J, LEWIS-JONES DI, TRIVERS RL, SINGH D, THORNHILL R, ROHDE P, BERECZKEI T, HENZI P, SOLER M, SZWED A: The 2nd:4th digit ratio, sexual dimorphism, population differences, and reproductive success. evidence for sexually antagonistic genes? Evol Hum Behav 21: 163-183, 2000. https://doi.org/10.1016/S1090-5138(00)00029-5

MANNING JT, FINK B: Digit ratio (2D:4D), dominance, reproductive success, asymmetry, and sociosexuality in the BBC Internet Study. Am J Hum Biol 20: 451-461, 2008. https://doi.org/10.1002/ajhb.20767

MANNING JT, ROBINSON SJ: 2nd to 4th digit ratio and a universal mean for prenatal testosterone in homosexual men. Med Hypotheses 61: 303-306, 2003. https://doi.org/10.1016/S0306-9877(03)00184-1

MANNING JT, SCUTT D, WILSON J, LEWIS-JONES DI: The ratio of 2nd to 4th digit length: a predictor of sperm numbers and concentrations of testosterone, luteinizing hormone and oestrogen. Hum Reprod 13: 3000-3004, 1998. https://doi.org/10.1093/humrep/13.11.3000

MCCARTHY MM, WRIGHT CL, SCHWARZ JM: New tricks by an old dogma: mechanisms of the Organizational/Activational Hypothesis of steroid-mediated sexual differentiation of brain and behavior. Horm Behav 55: 655-665, 2009. https://doi.org/10.1016/j.yhbeh.2009.02.012

MOFFAT SD, HAMPSON E: A curvilinear relationship between testosterone and spatial cognition in humans: possible influence of hand preference. Psychoneuroendocrinology 21: 323-337, 1996. https://doi.org/10.1016/0306$\underline{4530(95) 00051-8}$

MOROTE J, TABERNERO AJ, ALVAREZ OSSORIO JL, CIRIA JP, DOMINGUEZ-ESCRIG JL, VAZQUEZ F, ANGULO J, LOPEZ FJ, DE LA IGLESIA R, ROMERO J: Cognitive function in patients with prostate cancer receiving luteinizing hormone-releasing hormone analogues: a prospective, observational, multicenter study. Int J Radiat Oncol Biol Phys 98: 590-594, 2017. https://doi.org/10.1016/j.ijrobp.2017.02.219

MRAZIK M, DOMBROWSKI SC: The neurobiological foundations of giftedness. Roeper Rev 32: 224-234, 2010. https://doi.org/10.1080/02783193.2010.508154

NATHAN L, SHI W, DINH H, MUKHERJEE TK, WANG X, LUSIS AJ, CHAUDHURI G: Testosterone inhibits early atherogenesis by conversion to estradiol: critical role of aromatase. Proc Natl Acad Sci U S A 98: 3589-3593, 2001. https://doi.org/10.1073/pnas.051003698

O'BOYLE MW, ALEXANDER JE, BENBOW CP: Enhanced right hemisphere activation in the mathematically precocious: a preliminary EEG investigation. Brain Cogn 17: 138-153, 1991. https://doi.org/10.1016/0278$\underline{2626(91) 90073-\mathrm{H}}$

O'CONNOR DB, ARCHER J, HAIR WM, WU FC: Activational effects of testosterone on cognitive function in men. Neuropsychologia 39: 1385-1394, 2001. https://doi.org/10.1016/S0028-3932(01)00067-7

OERTER KE, URIARTE MM, ROSE SR, BARNES KM, CUTLER GB JR: Gonadotropin secretory dynamics during puberty in normal girls and boys. J Clin Endocrinol Metab 71: 1251-1258, 1990. https://doi.org/10.1210/jcem$\underline{71-5-1251}$

OSTATNIKOVA D, CELEC P, PUTZ Z, HODOSY J, SCHMIDT F, LAZNIBATOVA J, KUDELA M: Intelligence and salivary testosterone levels in prepubertal children. Neuropsychologia 45: 1378-1385, 2007. https://doi.org/10.1016/j.neuropsychologia.2006.10.018

OSTATNIKOVA D, HODOSY J, SKOKNOVA M, PUTZ Z, KUDELA M, CELEC P: Spatial abilities during the circalunar cycle in both sexes. Learn Indiv Differ 20: 484-487, 2010. https://doi.org/10.1016/j.lindif.2010.05.004

OSTATNIKOVA D, KUBRANSKA A, MARCINCAKOVA V, PIVOVARCIOVA A, BABKOVA-DURDIAKOVA J: Neuroendocrine contribution to autism etiology. Act Nerv Super Rediviva 58: 65-68, 2016. 
OSTATNIKOVA D, LAZNIBATOVA J, PUTZ Z, MATASEJE A, DOHNANYIOVA M, PASTOR K: Salivary testosterone levels in intellectually gifted and non-intellectually gifted preadolescents: an exploratory study. High Abil Stud 11: 41-54, 2000. https://doi.org/10.1080/713669174

OSTATNIKOVA D, LAZNIBATOVA J, PUTZ Z, MATASEJE A, DOHNANYIOVA M, PASTOR K: Biological aspects of intellectual giftedness. Studia Psychol 44: 3-13, 2002.

PETERING RC, BROOKS NA: Testosterone therapy: Review of clinical applications. Am Fam Physician 96: 441-449, 2017.

PHOENIX CH, GOY RW, GERALL AA, YOUNG WC: Organizing action of prenatally administered testosterone propionate on the tissues mediating mating behavior in the female guinea pig. Endocrinology 65: 369-382, 1959. https://doi.org/10.1210/endo-65-3-369

PINTZKA CW, EVENSMOEN HR, LEHN H, HABERG AK: Changes in spatial cognition and brain activity after a single dose of testosterone in healthy women. Behav Brain Res 298: 78-90, 2016. https://doi.org/10.1016/j.bbr.2015.10.056

PIVOVARCIOVA A, HNILICOVA S, OSTATNIKOVA D, MACE FC: Testosterone and explosive aggression in autism spectrum disorders. Neuro Endocrinol Lett 35: 553-559, 2014.

PIVOVARCIOVA A, HNILICOVA S, OSTATNIKOVA D, MACE FC: Bio-behavioral model of aggression in autism spectrum disorders-pilot study. Bratisl Lek Listy 116: 702-706, 2015. https://doi.org/10.4149/BLL_2015_137

PUTS DA, CARDENAS RA, BAILEY DH, BURRISS RP, JORDAN CL, BREEDLOVE SM: Salivary testosterone does not predict mental rotation performance in men or women. Horm Behav 58: 282-289, 2010. https://doi.org/10.1016/j.yhbeh.2010.03.005

RAY WJ, NEWCOMBE N, SEMON J, COLE PM: Spatial abilities, sex differences and EEG functioning. Neuropsychologia 19: 719-722, 1981. https://doi.org/10.1016/0028-3932(81)90010-5

REINBERG A, LAGOGUEY M, CHAUFFOURNIER JM, CESSELIN F: Circannual and circadian rhythms in plasma testosterone in five healthy young Parisian males. Acta Endocrinol (Copenh) 80: 732-734, 1975. https://doi.org/10.1530/acta.0.0800732

RITCHIE SJ, COX SR, SHEN X, LOMBARDO MV, REUS LM, ALLOZA C, HARRIS MA, ALDERSON HL, HUNTER S, NEILSON E, LIEWALD DCM, AUYEUNG B, WHALLEY HC, LAWRIE SM, GALE CR, BASTIN ME, MCINTOSH AM, DEARY IJ: Sex differences in the adult human brain: evidence from 5216 UK biobank participants. Cereb Cortex 28: 2959-2975, 2018. https://doi.org/10.1093/cercor/bhy109

ROMEO RD, RICHARDSON HN, SISK CL: Puberty and the maturation of the male brain and sexual behavior: recasting a behavioral potential. Neurosci Biobehav Rev 26: 381-391, 2002. https://doi.org/10.1016/S01497634(02)00009-X

RUIGROK AN, SALIMI-KHORSHIDI G, LAI MC, BARON-COHEN S, LOMBARDO MV, TAIT RJ, SUCKLING J: A meta-analysis of sex differences in human brain structure. Neurosci Biobehav Rev 39: 34-50, 2014. https://doi.org/10.1016/j.neubiorev.2013.12.004

RYLAARSDAM L, GUEMEZ-GAMBOA A: Genetic causes and modifiers of autism spectrum disorder. Front Cell Neurosci 13: 2019. https://doi.org/10.3389/fncel.2019.00385

SANDERS B, SOARES MP: Sexual maturation and spatial ability in college students. Dev Psychol 22: 199-203, 1986. https://doi.org/10.1037/0012-1649.22.2.199

SANDIN S, LICHTENSTEIN P, KUJA-HALKOLA R, HULTMAN C, LARSSON H, REICHENBERG A: The heritability of autism spectrum disorder. JAMA 318: 1182-1184, 2017. https://doi.org/10.1001/jama.2017.12141

SHUTE VJ, PELLEGRINO JW, HUBERT L, REYNOLDS RW: The relationship between androgen levels and human spatial abilities. Bull Psychon Soc 21: 465-468, 1983. https://doi.org/10.3758/BF03330010

SCHMIDTOVA E, KELEMENOVA S, CELEC P, FICEK A, OSTATNIKOVA D: Polymorphisms in genes involved in testosterone metabolism in Slovak autistic boys. Endocrinologist 20: 245-249, 2010. https://doi.org/10.1097/TEN.0b013e3181f661d2

SCHULZ KM, ZEHR JL, SALAS-RAMIREZ KY, SISK CL: Testosterone programs adult social behavior before and during, but not after, adolescence. Endocrinology 150: 3690-3698, 2009. https://doi.org/10.1210/en.2008-1708 
SKLAR P, SVANTESSON O, REICHENBERG A, HULTMAN CM, DEVLIN B, ROEDER K, BUXBAUM JD, JIANG YH, YUEN RK, JIN X, WANG M, CHEN N, WU X, JU J, MEI J, SHI Y, HE M, WANG G, LIANG J, WANG Z, ET AL.: Detection of clinically relevant genetic variants in autism spectrum disorder by wholegenome sequencing. Nat Genet 93: 249-263, 2013. https://doi.org/10.1016/j.ajhg.2013.06.012

SMITH RP, COWARD RM, KOVAC JR, LIPSHULTZ LI: The evidence for seasonal variations of testosterone in men. Maturitas 74: 208-212, 2013. https://doi.org/10.1016/j.maturitas.2012.12.003

SUCHONOVA M, BORBELYOVA V, RENCZES E, KONECNA B, VLKOVA B, HODOSY J, OSTATNIKOVA D, CELEC P: Does the 2nd and 4th digit ratio reflect prenatal androgen exposure? Bratisl Lek Listy 120: 703-710, 2019. https://doi.org/10.4149/BLL_2019 119

TAN U, TAN M: Curvelinear correlations between total testosterone levels and fluid intelligence in men and women. Int J Neurosci 95: 77-83, 1998. https://doi.org/10.3109/00207459809000651

TAO M, YANG D, LIU W: Learning effect and its prediction for cognitive tests used in studies on indoor environmental quality. Energy Buildings 197: 87-98, 2019. https://doi.org/10.1016/j.enbuild.2019.05.044

TORDJMAN S, FERRARI P, SULMONT V, DUYME M, ROUBERTOUX P: Androgenic activity in autism. Am J Psychiatry 154: 1626-1627, 1997. https://doi.org/10.1176/ajp.154.11.1626-a

VUOKSIMAA E, KAPRIO J, ERIKSSON CJ, ROSE RJ: Pubertal testosterone predicts mental rotation performance of young adult males. Psychoneuroendocrinology 37: 1791-1800, 2012. https://doi.org/10.1016/i.psyneuen.2012.03.013

WABER DP: Sex differences in cognition: a function of maturation rate? Science 192: 572-574, 1976. https://doi.org/10.1126/science.1257795

WILSON CA, DAVIES DC: The control of sexual differentiation of the reproductive system and brain. Reproduction 133: 331-359, 2007. https://doi.org/10.1530/REP-06-0078

WITELSON SF, NOWAKOWSKI RS: Left out axons make men right: a hypothesis for the origin of handedness and functional asymmetry. Neuropsychologia 29: 327-333, 1991. https://doi.org/10.1016/0028-3932(91)90046-B

WRIGHT CL, HOFFMAN JH, MCCARTHY MM: Evidence that inflammation promotes estradiol synthesis in human cerebellum during early childhood. Transl Psychiatry 9: 58, 2019. https://doi.org/10.1038/s41398-018-0363-8

XU XJ, ZHANG HF, SHOU XJ, LI J, JING WL, ZHOU Y, QIAN Y, HAN SP, ZHANG R, HAN JS: Prenatal hyperandrogenic environment induced autistic-like behavior in rat offspring. Physiol Behav 138: 13-20, 2015. https://doi.org/10.1016/j.physbeh.2014.09.014

YAFFE K, EDWARDS ER, LUI LY, ZMUDA JM, FERRELL RE, CAULEY JA: Androgen receptor CAG repeat polymorphism is associated with cognitive function in older men. Biol Psychiatry 54: 943-946, 2003. https://doi.org/10.1016/S0006-3223(03)00115-X

YPSILANTI A, GANOU M, KOIDOU I, GROUIOS G: Digit ratio (2D:4D) in individuals with intellectual disability: investigating the role of testosterone in the establishment of cerebral lateralisation. Laterality 13: 527-544, 2008. https://doi.org/10.1080/13576500802117164 